NBER WORKING PAPER SERIES

\title{
CONSTRAINING MANAGERS WITHOUT OWNERS: GOVERNANCE OF THE NOT-FOR-PROFIT ENTERPRISE
}

\author{
Mihir A. Desai \\ Robert J. Yetman \\ Working Paper 11140 \\ http://www.nber.org/papers/w11140
NATIONAL BUREAU OF ECONOMIC RESEARCH
1050 Massachusetts Avenue
Cambridge, MA 02138
February 2005

We thank Marion Fremont-Smith, Allan Grossman, Doug Guthrie, Karen Horn, Andrew Metrick, Rosalie Wolf and participants at the Federal Reserve Bank of New York's conference on the Governance of Not-forProfit Organizations for helpful discussions and comments. Desai thanks the Division of Research at Harvard Business School for generous financial support. The views expressed herein are those of the author(s) and do not necessarily reflect the views of the National Bureau of Economic Research.

(C) 2005 by Mihir A. Desai and Robert J. Yetman. All rights reserved. Short sections of text, not to exceed two paragraphs, may be quoted without explicit permission provided that full credit, including $@$ notice, is given to the source. 
Constraining Managers without Owners: Governance of the Not-for-Profit Enterprise Mihir A. Desai and Robert J. Yetman

NBER Working Paper No. 11140

February 2005

JEL No. L30, G30, H40, K20

\begin{abstract}
In the absence of owners, how effective are the constraints imposed by the state in promoting effective firm governance? This paper develops state-level indices of the legal and reporting rules facing not-for-profits and examines the effects of these rules on not-for-profit behavior. Stronger non-distribution constraints are associated with greater charitable expenditures and foundation payouts while more stringent reporting requirements are associated with lower insider compensation. The paper also examines how governance influences an alternative metric of not-for-profit performance - the provision of social insurance. Stronger governance measures are associated with intertemporal smoothing of resources and greater activity in response to negative economic shocks.

Mihir A. Desai

Graduate School of Business Administration

Harvard University

Soldiers Field

Boston, MA 02163

and NBER

mdesai@hbs.edu

Robert J. Yetman

Graduate School of Management

University of California, Davis

AOB iV

One Shields Avenue

Davis, CA 95616

rjyetman@ucdavis.edu
\end{abstract}




\section{Introduction}

In the absence of owners, how effective are the constraints imposed by the state on insiders in providing for effective governance of firms? Ownership patterns may well substitute for legal protections complicating direct inferences on the efficacy of legal and reporting requirements. The not-for-profit sector is characterized by the absence of owners but the presence of legal and reporting rules. Indeed, the differentiating characteristic of not-for-profits is the legal constraint on the non-distribution of earnings to insiders. Additionally, reporting of various kinds - mandated by the government rather than the owners - is also required. The strength of these legal and reporting rules vary by state within the U.S. creating the opportunity to analyze the efficacy of legal and reporting rules in a setting without owners and without the complicating features of cross-country studies.

This paper analyzes the influence of state-varying legal and reporting rules on the behavior of public charities and private foundations from 1987 to 2000. If these entities are motivated purely by altruistic motives or if the rules themselves are ineffective, these governance constraints may have no effect on not-for-profit outcomes. Alternatively, some aspects of these governance constraints might constrain not-for-profit managers from exploiting the latitude afforded by the absence of owners and thereby improve firm performance. In order to consider these alternatives, we calculate a state-level index of the legal and reporting constraints facing not-for-profits. For legal constraints, we create an index of legal rules facing not-for-profits that is further subdivided into indices measuring explicit rules that strengthen the non-distribution constraint and more general, alternative enforcement mechanisms. For reporting rules, we create an index of reporting requirements allowing us to consider the role of both legal rules and reporting requirements in influencing not-for-profit behavior.

In order to assess the relevance of the governance environment to not-for-profit firms, these indices are related to measures of operating performance and insider compensation for public charities. The paper also analyzes the degree to which payouts by nonoperating foundations also vary with these governance metrics. Finally, the paper provides an alternative test of not-for-profit performance - the degree to which not-for-profits provide social insurance by building stocks of reserves and responding to local negative income shocks - and examines the effect of governance on firm performance through this test. Much as the efficiency of private 
firms is measured by their responsiveness to investment opportunities, this test capitalizes on the idea that not-for-profits should expand activity at times when their activity is most warranted that is, do they help when helping helps the most.

We find that the governance environment of not-for-profits is associated with differential performance by public charities and private foundations on several different margins. For public charities, the analysis demonstrates that stronger non-distribution constraints and reporting rules are associated with a greater fraction of expenditures devoted to charitable activities and a lower probability of undertaking inefficient fundraising activity. In addition to these effects on public charity behavior, stronger legal and reporting rules are also associated with lower insider compensation. With respect to private foundations, stronger non-distribution constraints and reporting rules are associated with larger payouts and a lower probability of delaying required payouts. As with public charities, stronger legal and reporting rules are associated with lower officer compensation relative to total expenses as well as to the pay of other employees for private foundations.

Finally, not-for-profits in states with stronger legal and reporting rules also intertemporally smooth resources more by attenuating the link between the raising of resources and charitable expenditures. This intertemporal smoothing appears to fulfill a social insurance objective as not-for-profits in states with stronger legal and reporting rules also respond to negative income shocks with greater activity. These results suggest that not-for-profits in states with stricter governance environments fulfill a social insurance objective more effectively.

In general, governance laws related to the non-distribution constraint and state level reporting requirements have the most influence on not-for-profit behaviors while more ambiguous legal rules associated with enforcement appear to have little effect. More specifically, disclosure and reporting rules are most effective in deterring excessive insider compensation while the non-distribution constraint is most effective in focusing activities toward charitable purposes. As hypothesized in the literature, these results suggest that the strength of the non-distribution constraint specifically is a critical factor in regulating the behavior of notfor-profit organizations and that disclosure requirements can also deter opportunistic insiders. In sum, stronger non-distribution constraints and reporting rules increase the fraction of overall 
expenditures dedicated to charitable causes, mitigate large expenditures on officer compensation, and help ensure the efficient provision and timing of not-for-profit activity.

The rest of this paper proceeds as follows. Section 2 reviews the related literature and motivates our empirical methodology. Section 3 discusses the data employed with particular emphasis on the indices of governance employed in the paper. Section 4 provides the results. Section 5 concludes.

\section{Related literature and empirical methodology}

This analysis of the governance of not-for-profits is related to the growing literature on the economic functioning of not-for-profits and the extensive literature on social insurance mechanisms.

\subsection{The Economics of Not-For-Profits}

Analyses of not-for-profit firms typically consider why particular economic activities are undertaken by not-for-profit firms. This literature emphasizes that not-for-profit firms are distinctive primarily because of the non-distribution constraint and that this constraint can lead to efficient provision by these entities in some sectors. The intuition of Hansmann (1980), as expressed in models of asymmetric information (Easley and O’Hara (1982)) or ex-post expropriation (Glaeser and Shleifer (2004)), suggests that sectors characterized by the inability to contract fully over quality will feature not-for-profit firms. The available evidence on the sectors where not-for-profits are most active is consistent with this interpretation.

These analyses are helpful in considering what types of activities are undertaken by notfor-profits but provide limited guidance on analyzing the dynamics of not-for-profit activities. Of course, understanding the dynamics of not-for-profit firms is critical to any assessment of the performance of not-for-profits, particularly as it relates to the role of governance. One exception to this is the view that, without owners and a traditional for-profit governance framework, notfor-profit organizations evolve into worker cooperatives where worker preferences, particularly elite worker preferences, determine activities. This view is framed within the context of not-forprofit hospitals in Pauly and Redisch (1973) and extended to other settings in Glaeser (2003). ${ }^{1}$

\footnotetext{
${ }^{1}$ The public finance literature has emphasized the responsiveness of contributions to taxes rather than the nature of the entity-level treatment of not-for-profits. See Bittker and Rahdert (1976) for a history of the exemption of notfor-profit and Hines (1998) for a discussion of the tax treatment of taxable income earned by not-for-profits.
} 
In parallel with this economics literature, a growing literature in the accounting field has examined the reporting behavior of not-for-profits. ${ }^{2}$

In addition to the relevant literature on not-for-profit firms, our analysis also frames notfor-profit firms within the larger literature on social insurance mechanisms. This large literature typically emphasizes programs that are explicitly designed to provides insurance, such as unemployment insurance (as in Hamermesh (1982) or Gruber (1997)), and their effects in allowing recipients to smooth consumption. The intuition of social insurance has been extended to the mechanisms that are operative between and within families (as in Hayashi, Altonji, and Kotlikoff (1995)) or through the progressivity of the tax code (as in Auerbach and Feenberg (2000) and Kniesner and Ziliak (2004)). While Cochrane (1991) alludes to the role of not-forprofits in smoothing consumption, we are unaware of any empirical efforts that conceptualize not-for-profits in this way. This is surprising given the large literature, summarized in RoseAckerman (1996), on the altruistic motives behind the donations that fund most not-for-profits. As described below, one of the tests we employ to assess the quality of not-for-profit performance is their level of intertemporal resource smoothing and their responses to negative local income shocks.

Finally, this examination of the governance environment of not-for-profits parallels the growing literature on the impact of legal and reporting rules on for-profit firm performance. As in La Porta et al. $(1997,1998)$ and subsequent work in the law and finance literature, these efforts can emphasize cross-country differences in legal rules or, as in Bushman, Piotroski and Smith (2004), differences in accounting procedures. As Shleifer and Vishny (1996) note, ownership patterns themselves can embody responses to weak legal rules; in this sense, examining not-for-profits where owners are absent allows us to examine how legal and reporting rules alone influence firm performance. In emphasizing within-country differences, this paper may be closest in spirit to Gompers, Ishii and Metrick (2003) who create firm-specific measures of governance and link these governance measures to subsequent firm performance. This effort can be considered an effort to import the emphasis on quantifiable measures of governance to the

\footnotetext{
${ }^{2}$ For example, Baber, Daniel, and Roberts (2002) find that not-for-profit managerial compensation is at least partially explained by variations in the relative performance of the not-for-profit suggesting that the pay-forperformance relationship documented in the for-profit sector is also present in the not-for-profit sector. Krishnan, Yetman, and Yetman (2004) find that not-for-profit managers opportunistically report their accounting results so as to attract higher levels of donations and to appear more "charitable" to regulators.
} 
fields of not-for-profit enterprises. The most closely related paper on not-for-profits is Fisman and Hubbard (2003) that links several attorney general powers as measured in 1977 to the endowment characteristics of not-for-profits.

\subsection{Empirical Methodology}

The nearly $\$ 1$ trillion in assets in the not-for-profit sector are deployed by two types of firms - private foundations and public charities - that, in aggregate, are equally sized. While both types of entities are $\$ 501(c)(3)$ organizations providing them with a differentiating tax status, they are distinguished by the number of funders and some legal requirements.

Specifically, private foundations are typically funded by a relatively small number of individuals, are required to pay out at least five percent of their assets regularly, are subject to a tax on net investment income, and typically make disbursements to public charities. Public charities are either those entities whose financial support is provided by the general public or the broad classes of educational, medical, and associated supporting organizations that are specifically accorded public charity status through the Internal Revenue Code. In part, the minimal payout requirement for private foundations is designed to prevent the creation of foundations for purely tax-minimizing purposes. ${ }^{3}$

In order to assess the efficacy of these governance rules, we separately consider the effects of our measures of state-level governance (described in detail below) on public charities and private foundations. For public charities, the sample consists of approximately 52,000 firmyear observations from 1987 to 2000. Our tests emphasize three margins on which poor performance within not-for-profit performance may be measured- the focus on charitable activities, the efficiency of fundraising, and the level of insider compensation. ${ }^{4}$ In order to consider the degree to which public charities are focused on charitable purposes (rather than administrative or fundraising expenses), we analyze the relationship between legal and reporting rules and the ratio of charitable expenses to total expenses and the ratio of charitable expenses to total revenues. Fundraising activities, rather than serving to effectively raise funds, can serve the interests of insiders through extensions of social networks and the consumption of perquisites.

\footnotetext{
${ }^{3}$ See Marsh (2002) for a discussion of the historic rationale for the distinction between private foundations and public charities.

${ }^{4}$ Of course, these measures of performance are largely efficiency metrics. The social insurance mechanism we outline below provides a more nuanced notion of performance.
} 
Accordingly, we also analyze an indicator variable intended to measure inefficient fundraising activities. An indicator variable is set equal to one if the ratio of fundraising expenses to donations is equal to 1.0 or greater, and zero otherwise. An average ratio in excess of 1.0 is suggestive of excessive or inefficient expenditures on fundraising. Insider compensation is the other margin of not-for-profit behavior emphasized in this analysis. In order to measure compensation of insiders controlling the public charity, the ratios of officer compensation to total expenses and of officer compensation to other employee compensation are employed. ${ }^{5}$ Neither of these measures are perfect measures of poor performance or excessive compensation but do serve to measure the degree to which elite workers within public charities are benefiting from firm resources through either direct compensation, inefficient fundraising or non-charitable expenditures.

Turning to private foundations, the sample consists of approximately 38,000 firm-year observations from 1994 to 2000. We examine the relationships between governance and foundation payouts and foundation managerial compensation. The rationale for examining the compensation of foundation managers parallels that for public charity managers. Foundation payout policies are of particular interest as they capture the degree to which foundations distribute what is minimally required by rules. As the tax deduction for a contribution to a private foundation occurs when the foundation receives the funds rather than when it is eventually distributed to a public charity, rules requires minimal distribution amounts to ensure that foundations are not advancing purely tax avoidance through transfers of assets to foundations (Steuerle 1977). Prevailing rules require that foundations meet a minimum distribution requirement by spending at least five percent of their assets on charitable grants or charitable administrative expenditures in the current or following year (§4942). The minimum distribution requirement has been the subject of considerable controversy, with public charity advocacy groups calling for increases in the percentage of assets that must be annually paid out while foundation groups defend the current rules. ${ }^{6}$

\footnotetext{
${ }^{5}$ Officers compensation includes any amounts (wages, benefits, bonuses, etc.) paid to employees who have decision control over a not-for-profit's operations or finances.

${ }^{6}$ See Cambridge Associates (2000) and Mehrling (1999). Brody (1997) examines the broader questions of whether the non-profit sector should even have an endowment, whether this endowment should be controlled by private foundations instead of public charities, and whether private foundations should be allowed to exist in perpetuity. Hansmann (1990) criticizes the accumulation of wealth by universities on grounds of inter-generational equity.
} 
Our first measure of foundation payout is the ratio of current year payouts to the required amount (i.e., five percent of assets). The current payout amount is line 8 of Part V of the IRS 990, and the minimum required amount is line 7 of Part XI of the prior year's IRS 990-PF. We base the payout requirement on the prior year's amount as foundations can meet their payout obligations in the current year or in the following year (with any excess distributions carried forward to the subsequent year). Although many foundations distribute the legal minimum of five percent, some distribute more than is required. Our second measure of charitable payout is an indicator variable equal to one if the foundation delays its payout as long as possible (i.e., until the following year) and zero otherwise. This variable is the ratio of the current year payout (line 8 of Part V of the IRS 990) to the amount of remaining undistributed amounts left over from the prior year that must be distributed by the end of the current year (line 2a Column C Part XIII of the IRS 990-PF). By systematically delaying its payout, a foundation can retain its assets longer.

Finally, the conceptualization of not-for-profits firms as providing social insurance is tested using methods drawn from the financial economics literature. Typically, tests of the efficiency of investment, as in the setting of conglomerates, employ proxies for investment opportunities, typically industry $q$, to assess whether firm investment is responding to relevant opportunities. In the not-for-profit setting, the intuition of social insurance suggests that activity should increase in response to negative economic shocks when the marginal productivity of notfor-profit activities becomes greatest. ${ }^{7}$ Said another way, not-for-profits fulfilling their mission should disproportionately respond during distressed times as this is when their investment opportunities are the greatest. Accordingly, we test if not-for-profits respond differentially to local economic shocks depending on their governance environment.

This test of the efficiency of not-for-profit activity has several advantages. First, it provides a measure of performance that is not entirely cost-driven in a setting where output is hard to measure. Second, the intuition of investment opportunities corresponds to the espoused goals of a variety of not-for-profits. Of course, such a test is a reduced form of a fuller model. Such a model conceives of not-for-profit firms intertemporally smoothing activity in response to

\footnotetext{
${ }^{7}$ Alternatively, the concavity of utility functions provides the same intuition. That is, not-for-profits that best internalize the utility functions of their customers will expand activity during periods when marginal utility is highest.
} 
investment opportunities and this responsiveness is muted by the principal-agent problem that exists between funders and managers. Such a model, while beyond the scope of this paper, seems promising and would result in the reduced form which is tested here.

We operationalize this notion of insurance using two empirical tests. First, for insurance to be provided, there has to be some element of intertemporal smoothing where funds are gathered during some periods (typically economically robust ones) and saved for later periods when they are most effective. In order to identify the presence of intertemporal smoothing, we examine how governance influences the relationship between changes in total revenue sources (including donations, the sales of products and services, and other income) and changes in charitable expenditures. If well-governed firms are intertemporally smoothing, the governance variable should attenuate the relationship between the sources of funds and the disbursement of those funds.

Such intertemporal smoothing need not be for purposes associated with the needs of notfor-profit beneficiaries. In order to examine if this intertemporal smoothing has an insurance component, we examine if measures of governance influence the relationship between changes in local economic conditions (such as disposable income, gross state product, and unemployment levels) and changes in charitable expenditures. Local positive income shocks may well increase resource flows to not-for-profits permitting them to increase their charitable outputs. However, an insurance objective would be fulfilled if a positive relationship between local economic conditions and charitable output would be mitigated in well-governed firms. Said another way, the intertemporal smoothing identified in the first test could be characterized as insurance if this second test demonstrates that negative shocks are associated with increased activity for wellgoverned firms.

\section{Data and Descriptive Statistics}

\subsection{Governance Measures ${ }^{8}$}

As is emphasized in the literature on not-for-profits, the governance of not-for-profits is split between federal and state authorities. At the federal level, the Internal Revenue Service is charged with overseeing not-for-profit organizations. Although the IRS has the ability to revoke

\footnotetext{
${ }^{8}$ Our analysis of governance emphasizes legal and reporting rules. Of course, board structure and selection can also be a meaningful aspect of not-for-profit governance.
} 
a not-for-profits tax-exempt status in response to misbehavior, it rarely does so. As a practical matter, the majority of not-for-profit oversight is provided by various state-level agencies.

Because there is substantial variation in state-level not-for-profit legal regulation, we employ this variation in our empirical analysis. ${ }^{9}$ We use seven measures of a state’s legal power to regulate not-for-profits, which naturally subdivide - one rooted in preventing expropriation of charitable assets by managers and the other rooted in the mechanisms through which the enforcement of these powers take place. The expropriation rules are directly related to the non-distribution constraint. As noted by Hansmann (1980), the non-distribution constraint is designed to prevent asset expropriation and it is this constraint that distinguishes the not-for-profit form of business. Table 1a describes the construction of the indices and the precise powers that are characterized in these indices.

In the absence of oversight by either stockholders or the capital market, not-for-profit managers can divert charitable assets toward themselves in many ways including non-armslength sales of assets, consuming perquisites, or retaining charitable assets upon dissolution. To prevent expropriation, states have instituted several laws and we use the most common four as outlined in Fremont-Smith (2004). First, a state can legally distinguish not for profits from forprofit firms. By applying a unique set of statutory law to not-for-profits, a state can more easily act to prevent the distribution of charitable assets (i.e., residual claims) to officers, directors, or other specific individuals other than recipients specifically included in the organization by-laws. Second, states can require that liquidating distributions be made by not-for-profits only to other not-for-profits. By requiring that only another not-for-profit can receive the liquidating distributions of another not-for-profit a state effectively limits the payment of liquidating distributions to insiders. Third, states can enact laws that require that the State Attorney General be notified of not-for-profit asset sales. Again, this law prevents not-for-profits from systematically disposing of their assets, particularly through below-market sales to officers or

\footnotetext{
${ }^{9}$ We are aware of only one other paper, Fisman and Hubbard (2003), that attempts to identify and measure statelevel measures of not-for-profit governance. Our measure of legal and reporting governance differs from their measure in several respects. First, we emphasize the non-distribution constraint given the literature's emphasis on this aspect of not-for-profits. Second, our measure is based on a recent re-evaluation of state level governance (Fremont-Smith 2004) that updates the 1974 laws, also characterized by Fremont-Smith, used by Fisman and Hubbard. Third, our measure includes several new state-varying governance measures included in the recent source that were not included in the prior version. Finally, we also construct a state-level measure of reporting requirements. We thank Marion Fremont-Smith for providing us with an advance copy of her publication, FremontSmith (2004).
} 
employees through so-called "slow liquidations." The fourth and final component of our nondistribution metric is whether state law limits not-for-profits from re-incorporating as for-profit corporations. This law acts to prevent charities from paying out their assets as distributions to new "shareholders" that could be officers, directors or non-charitable corporations.

The mechanisms a particular state can employ to enforce its provisions over not-forprofits also vary across states. Some states make their enforcement authority explicit by instituting specific laws. We use the most common monitoring and enforcement laws as contained in Fremont-Smith (2004). First, a state can require that the Attorney General must be notified of any legal suits involving charities. In this way the Attorney General is able to determine if there is any enforceable action that should simultaneously be undertaken. Second, a state can empower parties other than the Attorney General (such as officers, directors, or other employees) the standing to bring legal action against a not-for-profit. This law has the effect of exposing the charity to multiple sources of legal challenge. Third, states may allow for Cy pres, or the authority of the courts to modify the incorporated purpose of the organization if that organization's purpose became obsolete, wasteful, or otherwise impracticable.

In addition to variation in legal rules, states are also characterized by distinctive reporting requirements. These reporting requirements are applicable to organizations that solicit donations within the state. Each state has from zero to nine distinct financial reporting requirements imposed by a registration authority. The registration authority varies across the states, sometimes being the Attorney General but often is a board of charities. Our reporting governance metric is a linear combination of these nine different financial reporting requirements that are outlined in summary in Table $1 \mathrm{~b} .{ }^{10}$ Because it is possible that some larger organizations solicit donations in multiple states, our measure (which is based on the state of incorporation) will contain some measurement error. To determine if this effect influences our results we replicated our tests eliminating organizations that filed combined IRS 990s (combined 990s result when a parent organization reports the aggregated financial results of the various affiliated state organizations) with no change in the substance of our results.

\footnotetext{
${ }^{10}$ We collected these measures of various state not-for-profit reporting requirements from the Charitable Organization Multi-State Filing Project at www.multistatefiling.org.
} 
Our nine measures of reporting requirements fall into three general categories. The first category includes the two general reporting requirements of whether or not a state requires registration and if registration needs to be renewed annually. The second category includes five types of documents that a state could require to be included in the registration. These documents are the not-for-profits' financial statements, by laws, articles of incorporation, IRS tax-exempt determination letter (i.e., the IRS 1023), and any additional forms the state may require. The final category contains two miscellaneous items. Some states require that a not-for-profit disclose the name of any paid professional fundraising organizations used. Professional fundraisers frequently retain a portion of donations as a fee and remit remaining funds to charities. By using professional fundraisers and reporting only net donations a charity can appear to be raising fewer donations in a state, perhaps drawing less regulatory attention. Finally, some states require that organizations that solicit donations in their jurisdiction undergo a financial statement audit by Certified Public Accountants.

Tables 2a, $2 \mathrm{~b}$ and 3 provide these legal and reporting indices, respectively, and their components by state. The minimum value for the total legal index is 3 while the highest is 7 indicating substantial variation across states. The reporting index provides even more variation with some states requiring nothing and other states requiring all nine components of our reporting index. Our governance sub-indices are correlated with each other as the correlation coefficient between the non-distribution sub-index and the enforcement sub-index is 0.37 . Similarly, the correlation coefficient between the combined legal index and the reporting index is 0.32. In addition to including these three measures separately in our regression models, we also include various combinations of them including grouping the two legal governance metrics into a single legal governance measure as well as grouping all three measures into a single governance metric.

\subsection{Not-for-profit Organization Data}

All public charities and foundations with revenues over \$25,000 must file an IRS Form 990 (or in the case of a foundation, a 990-PF) annually. To ensure the wide dissemination of Form 990 information the IRS Statistics of Income (SOI) division sponsors the Urban Institute to 
collect the data and make it freely available on the Internet at www.guidestar.org. ${ }^{11}$ The public charity dataset includes the years from 1987 to 2000. The most recent year of our sample (2000) contains 15,669 observations, while the oldest (1987) contains 8,357. Each of the annual public charity datasets includes all charities with assets over \$10 million plus a stratified random sample of charities with assets less than $\$ 10$ million. This database contains 160,140 observations of which 65,195 are not educational (i.e., private high schools or universities) or medical (i.e., hospitals and medical research institutes) not-for-profits.

We restrict our analysis to the sample of 65,195 charitable not-for-profits (and exclude all educational or medical not-for-profits) for two reasons. First, these types of organizations are subject to several additional sources of state-level governance that are not related to the measures of governance we use for our analysis. For example, in addition to being subject to the typical powers of a state Attorney General, medical not-for-profits are subject to oversight by state licensing and medical boards. In contrast, charitable not-for-profits are regulated by a single state agency and their powers correspond to our governance metric. Second, many states exempt educational and medical not-for-profits from the reporting requirements that we employ. These exemptions are granted because medical and educational not-for-profits generally must file particular regulatory forms with the state agencies that oversee them. Unfortunately, we are not aware of any reliable source that would permit us to construct a legal or a reporting governance metric for educational or medical not-for-profits. We further reduce our sample of 65,795 charitable not-for-profits to 51,917 by requiring that they receive donations of a least $\$ 10,000$. Charities that receive few donations are frequently not subject to state reporting requirements and are less likely to be subject to enforcement efforts by state oversight agencies.

The foundation dataset spans the years 1994 through 2000. The 1994 database includes the entire population of 50,914 foundations, while the 1995 to 2000 samples include approximately 8,000 observations for each year. The sample observations for 1995 to 2000 were compiled by the IRS and include all foundations with total year-end assets of $\$ 10$ million or more as well as a stratified random sample of smaller foundations. We exclude 6,909 private operating foundation observations, which operate charitable programs rather than make grants

\footnotetext{
${ }^{11}$ Computer readable data is available from the National Center for Charitable Statistics directly at www.nccs.urban.org.
} 
and face a different set of tax rules. We also exclude 2,654 foundation-year observations with zero assets. $^{12}$

Descriptive statistics for the variables employed in the paper are presented in Table $4 .^{13}$ Although the organization-specific characteristics we examine vary from year to year, our governance metrics do not. We did attempt to gain some understanding of the extent to which these various governance mechanisms have been stable over time, particularly during our sample periods. Discussions with various individuals at various state not-for-profit regulating agencies suggest that in general the existing rules have been in place for at least the past several years. Because the governance variables do not vary across time, all standard errors are clustered at the entity level. Additionally, because the charitable sector is diverse we also include industry indicator variables in our regression analyses. The IRS has created a National Taxonomy of Exempt Entities (NTEE) which include 18 major categories (and numerous sub-categories) of charitable not-for-profits.

\section{4. $\quad$ Results}

\subsection{Public Charities}

As previously discussed the empirical analysis is directed towards addressing two broad issues. First, does stronger governance induce not-for-profits to focus more on charitable activities? Second, does stronger governance attenuate payments (in the form of salaries) to insiders? Table 5 initiates our analysis with an examination of how our governance metrics influence the charitable payout and fundraising activities of public charities. Industry, size (total assets) and revenue controls are included in all regressions. All t-statistics are based on standard errors clustered at the firm level. Several variations of each model are presented in order to examine the independent and joint effects of the governance variables.

The measure of charitable payout in columns 1 through 6 is the ratio of charitable expenses to total expenses. This measures captures the relative proportion of total expenditures

\footnotetext{
${ }^{12}$ Zero asset foundations frequently act as little more than annual conduits where a donor provides funds to the foundation, which disburses those funds to a charity before the end of the year.

${ }^{13}$ Because the foundation sector is diverse and our sample contains observations with extreme minimum and maximum values of many of our variables of interest we attempt to mitigate the influence of extreme values on our analyses in several ways. First, we winsorize all of our data at the $1^{\text {st }}$ and $99^{\text {th }}$ percentiles. Second, we conduct extensive outlier testing in each regression model including examining residual plots and screening our data based on Cook's D statistics, leverage statistics, and standardized residual statistics.
} 
that are devoted to charitable causes rather than consumed as administrative expenses or spent on fundraising activities. ${ }^{14}$ The results in column 1 of Table 5 indicate that the combined governance variable is associated with a larger share of not-for-profit expenses being dedicated to charitable purposes. When we partition the combined governance variable into its three subindices (non-distribution, enforcement, and reporting) in columns 2-6 of Table 5, results suggest that the enforcement sub-index has no independent effect on public charity behavior. In contrast the non-distribution and reporting governance variables each has a statistically significant effect on public charity behavior. Columns 7 through 12 of Table 5 repeat this analysis using the share of total revenue as a scaling factor in order to capture the relative amount of total current resources that are devoted to charitable purposes. Scaling by revenues is a useful check on these results as a not-for-profit can spend its current inflows on charitable, administrative, or fundraising activities but it may alternatively choose to save a portion of those inflows. Results for this alternative measure of charitable payout are similar to those obtained when scaling by total expenses suggesting that intertemporal dynamics or the stage of not-for-profit growth does not account for the observed results. In terms of economic magnitude the results suggest that increasing non-distribution governance from the $25^{\text {th }}$ percentile to the $75^{\text {th }}$ percentile (a change of 1.0) induces an approximately one percent increase in expenses dedicated toward charitable purposes. A similar magnitude applies to the results on reporting governance.

Columns 13 through 18 of Table 5 employ a dependent variable that measures the efficiency of fundraising. As noted by Steinberg (1986), a not-for-profit will benefit financially by increasing its fundraising activities until the marginal cost of fundraising is equal to marginal donation revenues. ${ }^{15}$ The fundraising metric we employ is an indicator variable equal to one if the ratio of fundraising expenses to total donations is equal to or greater than 1.0 and zero otherwise. This average measure, although not identical to the underlying marginal metric,

\footnotetext{
${ }^{14}$ We define charitable expenses as those reported as "program expenses” in Part II of Page 2 of the IRS 990. On page 2 a charity must partition all of its expenses into one of three mutually exclusive categories; programs, administrative, and fundraising.

${ }^{15}$ Rose-Ackerman (1982) provides a formal analysis of the issue of "excessive" fundraising and finds that donors (who favor a particular type of public good) gain from fundraising to the extent it attracts other donors to their charity and lose to the extent that donations are diverted away from their favored charity towards alternative competing charities. This substitution effect can cause waste to the extent it merely increases overall fundraising expenditures without increasing the amount of overall donations in the market.
} 
captures the notion of "excessive” fundraising. These specifications employ a logit model. ${ }^{16}$ These results indicate that the combined governance variable is associated with a lower probability of incurring “excessive” fundraising expenses. When we partition the combined governance variable into its three sub-indices (non-distribution, enforcement, and reporting) results show that the enforcement sub-index has no independent effect but that the nondistribution and reporting governance variables each has a statistically significant effect on fundraising, consistent with the results found for charitable expenditures above. In terms of magnitudes, the results suggest that increasing non-distribution (reporting) governance from the $25^{\text {th }}$ percentile to the $75^{\text {th }}$ percentile induces an approximately 14 (12) percent decrease in probability that a public charity will engage in excessive fundraising.

The importance of the non-distribution laws and reporting laws relative to general enforcement variables is something that persists in our analysis. Given that the non-distribution constraint is, as noted by Hansmann (1980), the differentiating characteristic of not-for-profits, these results are reassuring. These laws act to prohibit specific activities such as self-dealing or indirect distributions. Similarly, the state level reporting laws are designed to lay bare the financial transactions of the not-for-profit. In contrast, state level laws regarding the enforcement powers of the state Attorney General do not correspond to specifically prohibited transactions or actual requirement but simply lay out what general powers the Attorney General has. These more general laws appear to have no effect on the behavior of not-for-profits.

Table 6 presents the results of tests intended to measure the effects of governance on insider compensation. ${ }^{17}$ Columns 1 through 6 show the effects of the governance metrics on the ratio of officers' compensation to total expenses. This ratio captures the relative amount of total expenditures that are paid to officers. Results show that the combined governance variable is not associated with the ratio of officers' compensation to total expenses. The results in subsequent columns (2 to 6) suggest that higher levels of reporting governance attenuate the ratio of officers' compensation to total expenses, but that neither of the legal subindices has any independent effect.

\footnotetext{
${ }^{16}$ As the descriptive statistics in Table 4 indicate, only six percent of the sample has this indicator variable set equal to one. Alternative specifications that employ a cutoff of 0.8 instead of 1 reach similar conclusions.

17 This figure is drawn from line 25 of Part II of the IRS 990 (line item description is "compensation of officers, directors, etc.”.
} 
One problem with using the ratio of compensation to total expense is that many not-forprofit employees, including officers, donate their services. To the extent that the donation of services is correlated with governance this test is not necessarily isolating the effects of governance on compensation per se. To overcome this potential weakness we use a second compensation metric defined as the ratio of officer's compensation to other employee (i.e., nonofficer) compensation. This ratio captures the relative amount of compensation that not-forprofits officers receive relative to the other employees. Columns 7 through 12 in Table 6 report results using this metric and show that higher combined governance is associated with lower amounts of officer's compensation relative to other employee compensation. When we partition the combined governance variable into its three sub-indices (non-distribution, enforcement, and reporting) results show that the enforcement sub-index has no independent effect but that the non-distribution and reporting governance variables each has a statistically significant and independent effects. In terms of magnitude the results suggest that increasing reporting governance from the $25^{\text {th }}$ percentile to the $75^{\text {th }}$ percentile (a change of 2.0 ) induces an approximately 0.1 percent decrease in the ratio of officer's compensation to total compensation.

As with charitable payout and fundraising behavior, the results suggest that laws regulating inappropriate distributions to insiders and reporting requirements have the strongest effect on officer's compensation. These results correspond to the intuition that excess compensation is deterred in the presence of laws that prohibit the distribution of assets to insiders and in the presence of reporting requirements the force not-for-profit managers to report their financials in detail.

\subsection{Private Foundations}

The analysis of private foundations parallels that conducted on public charities. Similar to public charities, foundations also make charitable payouts. An important distinction between foundations and charities is that foundations have a minimum payout requirement while charities do not. Again we seek to address two basic issues; does stronger governance cause foundations to pay out more than the minimally required amount, and does stronger governance attenuate payments (in the form of salaries) to insiders? Columns 1 through 6 of Table 7 examine the effects of governance on the amount of foundation payouts relative to legally required minimum 
amount of five percent of assets. ${ }^{18}$ The results in column 1 of Table 7 show that the combined governance variable is associated with larger foundation payouts relative to the required amount. When we partition the combined governance variable into its three sub-indices (non-distribution, enforcement, and reporting) as in columns 2-6 of Table 7, results suggest that the nondistribution and reporting governance variables each has a statistically significant effect on foundation payouts while the enforcement sub-index has no independent effect on foundation payouts. These results suggest that an increase in non-distribution governance from the $25^{\text {th }}$ percentile to the $75^{\text {th }}$ percentile induces an approximately seven percent increase in foundation payouts relative to the required amount. A somewhat smaller magnitude (four percent) applies to reporting governance.

As discussed above, a foundation has two choices when making its payout decisions. The first choice is determining how much to payout (as examined in the columns 1 through 6 of Table 7) and the second choice is determining when to payout. Because foundations are permitted to delay their payouts one year they can retain their assets one additional year by deferring their payouts. The second six columns of Table 7 presents results using an indicator variable equal to one if the foundation delays the majority (i.e., 99 percent) of its payouts until the following year and zero otherwise. Results suggest that higher combined governance is associated with a lower probability of delay in foundation payouts. As with other results, the enforcement sub-index has no independent effect but the non-distribution and reporting governance variables each has a statistically significant and independent effects on foundation payout delay. In terms of magnitude the results suggest that increasing reporting governance from the $25^{\text {th }}$ percentile to the $75^{\text {th }}$ percentile induces an approximately 5 percent decrease in probability that a private foundation will delay its payouts as long as possible.

With respect to foundation officers' compensation ${ }^{19}$, results in the first column of Table 8 shows that higher levels of combined governance are associated with lower ratios of officers’ compensation to total compensation suggesting that stronger governance attenuates foundation officer's compensation. The partitioned results in columns 2 through 6 indicate that this effect stems from the non-distribution sub-index and that neither the enforcement subindex nor the

\footnotetext{
${ }^{18}$ The payout amount is line 8 of Part V of the IRS 990, and the minimum required amount is line 7 of Part XI of the prior year's IRS 990-PF.

${ }^{19}$ This figures is taken from line 13a of the IRS 990-PF.
} 
reporting governance measure are associated with the ratio of foundation officer's compensation to total expenses. Scaling by other employee compensation provide similar results, as indicated in columns 7 through 12 of Table 8 . In terms of magnitude the results suggest that increasing non-distribution governance from the $25^{\text {th }}$ percentile to the $75^{\text {th }}$ percentile induces an approximately 3 percent decrease in the ratio of officers compensation to total expenses. A similar change in non-distribution (reporting) governance induces a decrease in the ratio of officer compensation to other employee compensation of 37 (70) percent.

The results for foundation payouts are similar to those for public charity payouts and suggest that similar forms of governance laws have similar effects on not-for-profit behavior. This is somewhat surprising given that private foundations are more likely to have a significant donor who can exert significant control. Nonetheless, in both cases non-distribution laws and reporting requirements appear to be associated with higher charitable payouts in both types of not-for-profits. In part, this may be explained by the fact that the oversight of many foundations are provided by the families of donors and, more specifically, later generations of donors with less incentive to fulfill the charitable mission of the foundation. We leave this link between the presence of an actual donor and foundation behavior for future work.

\subsection{Not-for-Profits and Social Insurance}

The preceding analysis is useful in establishing empirical regularities between insider compensation, a focus on charitable purposes and the governance environment of the not-forprofit firms. This analysis, however, is subject to several criticisms. First, it does not employ the panel nature of the underlying data. Indeed, the results are subject to the same criticisms leveled at cross-country studies that relate firm performance or capital market conditions to governance. Second, it only emphasizes the cost-structure of not-for-profits without attempting to assess the degree to which not-for-profits are fulfilling their mission. In order to investigate further the importance of the governance environment on not-for-profits and to respond to these concerns, we turn to an analysis of whether not-for-profit firms fulfill a social insurance objective. While no ready summary statistic is available to assess the performance of not-for-profits, we employ the panel nature of the data to assess the degree to which not-for-profits are intertemporally smoothing resources and if they are, indeed, helping when helps the most. These tests, while novel in the setting of not-for-profits, employ the differential response to shocks to see if the 
relationship between resources and activities and between local economic conditions and not-forprofit activities is mediated by the governance environment. ${ }^{20}$

A social insurance object would be fulfilled if not-for-profits both intertemporally smooth resources and if they expend more resources when local economies are hardest hit. The intuition for intertemporal smoothing arises from the fact that a well governed not-for-profit would opt to limit the expansion of its charitable expenditures in flush times in order to build a reserve that can be employed in future bad times. In order to consider this possibility, Table 9 examines the relationship between not-for profit activities and the resources available to a not-for-profit, including donations, program revenues (from the sales of products and services) and revenues from the sales of assets. We partition the revenue sources into these three categories because they are very different. Donations are received from donors while program revenues are earned income. Asset sales are neither donated nor earned, but result from the organization disposing of a portion of its investment or plant assets. These three revenue categories comprise the vast majority (over 95 percent) of total organization revenues. To conduct this analysis we express all our variables as percentage changes and include year and industry effects.

The first two columns of Table 9 examine the link between these resources and not-forprofit expenses for charitable purposes and shows that, as available resources from donations and programs increases, the amount of charitable expenditures also increases. This finding is consistent with the intuition that increased resources are associated with increased expenditures. Results in the third column of Table 9 show that revenues from asset sales are not associated with increases in charitable expenditures. One likely cause for this result is that revenues derived from asset sales tend to be lumpy and are therefore less likely to have an impact on charitable expenditures. Of more interest than these main effects is the coefficient on the interaction of the governance variable and these resource variables. Results in Columns 1 and 2 suggest that the presence of stronger governance attenuates the increase in charitable outputs as resources from donations and programs rise. This finding is consistent with a social insurance effect in that charities in well governed states increase their charitable spending less as resources increase, saving some resources for poorer economic conditions. In columns 4, 5, and 6 of Table 9 we

\footnotetext{
${ }^{20}$ Because foundations are less subject to the effects of economy wide fluctuations (as they are predominantly funded by a single person) and typically pursue longer-term objectives, we exclude private foundations from this analysis.
} 
combine the measures of economic resources into single equations. Column 4 presents the combined results excluding the main effect of governance while the results in Column 5 include the governance main effect. The results in Column 6 also exclude the governance main effect but report clustered t-statistics. In all cases, the results show an insurance effect (as noted by a statistically negative sign on the interaction coefficient) for program revenues.

While these results indicate intertemporal smoothing of resources, particularly program revenues, it does not suggest that not-for-profits are increasing resources during economically difficult times. In order to consider this relationship, we consider the relationship between several measures of local economic conditions and charitable expenses. As no single measure best captures local needs, we employ changes in disposable income, disposable income per capita, gross state product, and state-level unemployment rates. The results in columns 1, 3, 5 and 7 in Table 10 indicate that as the overall economic situation of a state improves (as measured by higher state disposable income, higher state disposable income per capita, higher gross state product, and lower state unemployment rates) the amount of charitable expenditures by public charities likewise increases. These results suggest that not-for-profits are expanding and contracting in tandem with local economic cycles. When these economic variables are interacted with governance, the results in columns 2, 4, 6, and 8 indicate that the increases in charitable expenditures in response to economic activity are attenuated in higher governance states. In other words, not-for-profits in states providing a stricter governance environment are more likely to attenuate the relationship between local economic conditions and charitable expenditures, enabling them to provide more resources during more difficult economic times.

These results can be viewed as supporting the view that good governance rules help notfor-profit entities fulfill a social insurance function. While the coefficients on the interaction terms are supportive of this intuition, the coefficients on the local economic variables are not consistent with not-for-profits, on average, providing an insurance function as conceptualized in this paper. While the direct test of the effect of governance on not-for-profit is on the sign of the interaction term, the coefficients on the economic variables alone indicate the degree to which not-for-profits remain tied to local economic conditions. Further analysis might usefully examine the other factors that allow not-for-profit firms to fulfill a social insurance function.

\section{Conclusion}


The not-for-profit sector, consisting of public charities and private foundations, is a significant part of the U.S. economy. Public charities face several important operating choices including how much financial resources to devote to charitable rather than administrative activities, how much to spend on fundraising, and how to compensate their officers. Private foundations likewise face important choices including how much of their assets to give away to charities annually, when to pay those gifts, and how much to compensate their officers. These choices are central and fundamental to the overall operating effectiveness of the charitable sector and are remarkably unconstrained by the usual mechanisms that constrain for-profit managers. In the absence of the governance normally provided by owners, not-for-profits are subject to oversight and monitoring by various state-level agencies. Although this situation is well known, what is not known is how effective these legal and reporting rules are in controlling the behavior of not-for-profit managers.

The governance environment facing not-for-profit firms appears to shape their emphasis on charitable activities, their compensation patterns, their willingness to engage in inefficient fundraising, and their willingness to smooth and time their activities most effectively. These findings are consistent with the notion that state-level laws and regulations constitute an effective governance environment in the absence of owners. The results further suggest that the more general enforcement provisions that outline the legal authority of state attorney generals have little or no effect on not-for-profit firm behavior while specific rules that strengthen the nondistribution constraint or mandate fuller reporting provide the largest effects on not-for-profit behavior. Finally, our analysis finds that strong governance rules also appear to enhance the willingness of not-for-profits to intertemporally smooth their activities and expand activities when local economic conditions worsen. This finding is suggestive of a social insurance function for not-for-profits as well-governed entities moderate their spending in good economic periods in order to expand their charitable activities in less robust economic periods.

This analysis also suggests several lines of further inquiry. First, the diffusion of funders of not-for-profits might usefully be analogized to the concentration of ownership to examine how not-for-profit firms respond to the presence of large funders. One possible avenue for this would be to consider the role of government grants, or large block grants received from feeder organizations such as the United Way. Second, the effects of large liquid endowments on charitable behavior, analogous to the free cash flow problem encountered in for-profit 
corporations, is a relatively unexplored area. Third, the extent to which legacy effects alter private foundation payouts has not been examined. The payout philosophy of a foundation could be a function of whether or not the originating founder is still alive or a function of the influence of the founder's heirs on foundation payouts. Each of these questions could be analyzed within the framework of the governance environment articulated in this paper. We leave these questions for future research. 


\section{References}

Auerbach, A.J., Feenberg, D., 2000. The Significance of Federal Taxes as Automatic Stabilizers. Journal of Economic Perspectives. 14:37-56.

Baber, W., Daniel P. and Roberts, A., 2002. Compensation to managers of charitable organizations, An empirical study of the role of accounting measures of program activities. Accounting Review 77: 679-694.

Bittker, B.I., Radhert, G.K., 1976. The Exemption of Nonprofit Organizations From Federal Income Taxation. The Yale Law Journal. 85 (3): 299-358.

Brody, E., 1997. Charitable Endowments and the Democratization of Dynasty. Arizona Law Review 39 (Fall): 873-948.

Bushman, R., Piotroski, J., Smith, A., 2004. What Determines Corporate Transparency? Journal of Accounting Research. 42:207-252

Cambridge Associates, 2000. Sustainable Payout for Foundations. Cambridge Associates, Inc.: Cambridge, MA.

Cochrane, J.H., 1991. A Simple Test of Consumption Insurance. The Journal of Political Economy. 99: 957-976.

Fisman, R., Hubbard, G., 2003. Endowments, Governance, and the Nonprofit Form. The Governance of Not-for-Profit Organizations. The University of Chicago Press.

Glaeser, E. L., Shleifer, A., 2001. Not-for-profit entrepreneurs. Journal of Public Economics. 81: 99-115.

Glaeser, E., 2003. Introduction. The Governance of Not-for-Profit Organizations. The University of Chicago Press.

Gompers, P., Ishii, J., and Metrick, A., 2003 "Corporate Governance and Equity Prices." Quarterly Journal of Economics 118: 107-155.

Gruber, J., 1997. The Consumption Smoothing Benefits of Unemployment Insurance. The American Economic Review. 87: 192-205.

Hamermesh, D.S., 1982. Social Insurance and Consumption: An Empirical Inquiry. The American Economic Review. 72: 101-113.

Hansmann, H., 1980. The Role of Nonprofit Enterprise. The Yale Law Journal. 89: 835-902.

Hansmann, H., 1990. Why do Universities have Endowments? Journal of Legal Studies19 (January): 3-42 
Hayashi, F., Altonji, J., Kotlikoff, L., 1996. Risk-Sharing between and within Families. Econometrica. 64: 261-294.

Hines, J., 1999. “Nonprofit Business Activity and the Unrelated Business Income Tax.” In James Poterba's ed., Tax Policy and the Economy. 13: 57-84.

Kingma, B.R., 1989. An Accurate Measurement of the Crowd-out Effect, Income Effect, and Price Effect for Charitable Contributions. The Journal of Political Economy. 97: 11971207.

Kniesner, T.J., Ziliak, J.P., 2004. Tax Reform and Automatic Stabilization. The American Economic Review. 92: 590-612.

Krishnan, R., Yetman, M., and Yetman, R., 2004. Cost Shifting in Nonprofit Organizations: An Agency Based Analysis. Working paper, the University of California at Davis.

La Porta, R., Lopes de Silanes, F., Shleifer, A., and Vishny, R., 1997, "Legal determinants of external finance,” Journal of Finance 52: 1131

La Porta, R., Lopes de Silanes, F., Shleifer, A., and Vishny, R., 1998, "Law and finance,” Journal of Political Economy 106: 1113-1155.

Marsh, T., 2002. A Dubious Distinction: Rethinking Tax Treatment of Private Foundations and Public Charities. Virginia Tax Review. 22. pp.

Mehrling, P., 1999. Spending Policies for Foundations: The Case for Increased Grants Payout. National Network of Grantmakers: San Diego, CA.

Pauly, M., Redishch, M., 1973. The Not-For-Profit Hospital as a Physicians’ Cooperative. The American Economic Review. 63: 87-99.

Rose-Ackerman, S., 1987., Charitable Giving and “Excessive” Fundraising. The Quarterly Journal of Economics. 97: 195-212.

Rose-Ackerman, S., 1996., Altruism, Nonprofits, and Economic Theory. Journal of Economic Literature. 34: 701-728.

Shleifer, A.and Vishny, R.,1996. A Survey of Corporate Governance, Journal of Finance, 52: 737-783.

Steinberg, R., 1986. Should Donors Care About Fundraising? In The Economics of Nonprofit Institutions, Edited by Susan Rose-Ackerman. Oxford University Press, Oxford.

Senate of the United States, 2003. Charity Aid, Recovery, and Empowerment Act of 2003. S 272. 
Steuerle, G., 1977. Pay-out Requirements for Foundations. U.S. Department of the Treasury: Washington, D.C.

United States House of Representatives, 2003. The Charitable Giving Act of 2003. HR 7. 
Table 1a

Description of Legal Governance Measures

Non-distribution Sub-Index Measures

Variable

Description

\begin{tabular}{|l|l|}
\hline $\begin{array}{l}\text { Not-for-profits legally } \\
\text { distinguished } \\
\text { from for-profit firms }\end{array}$ & $\begin{array}{l}\text { Some states have a unique set of statutory laws that apply specifically to not-for-profits. } \\
\text { One common element of these separate laws is that they typically act to prevent the } \\
\text { distribution of charitable assets (i.e., residual claims) to officers, directors, or other } \\
\text { specific individuals other than recipients specifically included in the organizations' by- } \\
\text { laws. }\end{array}$ \\
\hline $\begin{array}{l}\text { Liquidating distributions } \\
\text { restricted to other not-for- } \\
\text { profits }\end{array}$ & $\begin{array}{l}\text { Some states require that charitable liquidating distributions be paid to other registered } \\
\text { charities only. This prevents charities from paying assets to corporate officers or } \\
\text { directors or other non-charitable organizations. }\end{array}$ \\
\hline $\begin{array}{l}\text { Attorney General must be } \\
\text { notified of asset sales }\end{array}$ & $\begin{array}{l}\text { Some states require charities to notify the Attorney General if it sells substantially all of } \\
\text { its assets. This permits the Attorney General to enforce non-distribution rules on } \\
\text { charitable liquidations. }\end{array}$ \\
\hline $\begin{array}{l}\text { Limitations on re- } \\
\text { incorporating as a for- } \\
\text { profit corporation }\end{array}$ & $\begin{array}{l}\text { Some states prohibit or otherwise limit the extent to which charities can re-organize as } \\
\text { for-profit corporations. This prevents charities from paying out their assets to new } \\
\text { "shareholders" which could be officers or directors or non-charitable corporations. }\end{array}$ \\
\hline
\end{tabular}

Enforcement Rights Sub-Index Measures

Variable

Description

\begin{tabular}{|l|l|}
\hline $\begin{array}{l}\text { Attorney General must be } \\
\text { notified of any suits } \\
\text { involving charities }\end{array}$ & $\begin{array}{l}\text { Some states require the courts to notify the Attorney General of any legal action brought } \\
\text { against a charity. One purpose of this requirement is that it permits the Attorney General } \\
\text { to determine if there is any enforceable action it should undertake as well. }\end{array}$ \\
\hline $\begin{array}{l}\text { Parties other than Attorney } \\
\text { General have standing to } \\
\text { bring legal actions }\end{array}$ & $\begin{array}{l}\text { Some states give parties other than the Attorney General (such as officers or directors) the } \\
\text { right to bring legal suit against a charity. This exposes the charity to additional sources of } \\
\text { legal enforcement. }\end{array}$ \\
\hline Cy pres authority & $\begin{array}{l}\text { Cy pres laws give the courts the power to modify the incorporated purpose of the } \\
\text { organization if that organization's purpose became obsolete, wasteful, or otherwise } \\
\text { impracticable }\end{array}$ \\
\hline
\end{tabular}

Source: Fremont-Smith (2004). 
Table 1b

Description of Reporting Governance Measures

Variable

Description

\begin{tabular}{|l|l|}
\hline Registration required & $\begin{array}{l}\text { Most states exempt organizations that raise small amounts of donations (typically around } \\
\$ 10,000) \text {. Virtually all states exempt not-for-profit educational and medical } \\
\text { organizations from registration as these types of organizations typically have their own } \\
\text { state and frequently federal registration requirements. }\end{array}$ \\
\hline $\begin{array}{l}\text { Annual renewal of } \\
\text { registration }\end{array}$ & $\begin{array}{l}\text { For states that require registration the renewal period is generally either annual or never } \\
\text { (once the charity is registered it need never again register). }\end{array}$ \\
\hline $\begin{array}{l}\text { Fundraising organizations } \\
\text { used }\end{array}$ & $\begin{array}{l}\text { Some charities use professional fundraising firms which raise donations and remit those } \\
\text { donations, less a fee, to the charity. }\end{array}$ \\
\hline Financial statement audit & $\begin{array}{l}\text { Some states require the charity to undergo a financial statement audit by Certified Public } \\
\text { Accountants }\end{array}$ \\
\hline $\begin{array}{l}\text { Financial statements } \\
\text { included }\end{array}$ & $\begin{array}{l}\text { In addition to the IRS 990 (which is required to be included in all state registrations) } \\
\text { some states also require that financial statements be included. }\end{array}$ \\
\hline Bylaws included & Are bylaws included as part of required reporting? \\
\hline $\begin{array}{l}\text { Articles of incorporation } \\
\text { included }\end{array}$ & Are articles of incorporation included as part of required reporting? \\
\hline $\begin{array}{l}\text { Tax exempt determination } \\
\text { letter included }\end{array}$ & $\begin{array}{l}\text { The tax-exempt determination letter (the IRS 1023) is the formal document that exempts } \\
\text { a charity from federal income taxation. }\end{array}$ \\
\hline $\begin{array}{l}\text { Other state specific } \\
\text { information included }\end{array}$ & Some states have additional state-specific forms that must be included in the registration. \\
\hline
\end{tabular}

Source: Based on filing requirements as reported by the Charitable Organization Multi-State Filing Project. Further detail is available at www.multistatefiling.org. 
Table 2a

Legal Non-distribution Governance Sub-Index

State

Alaska

Alabama

Arkansas

Arizona

California

Colorado

Connecticut

DC

Delaware

Florida

Georgia

Hawaii

Iowa

Idaho

Illinois

Indiana

Kansas

Kentucky

Louisiana

Massachusetts

Maryland

Maine

Michigan

Minnesota

Missouri

Mississippi

Montana

North Carolina

North Dakota

Nebraska

New Hampshire

New Jersey

New Mexico

Nevada

New York

Ohio

Oklahoma

Oregon

Pennsylvania

Rhode Island

South Carolina

South Dakota

Tennessee

Texas

Utah

Virginia

Vermont

Washington

Wisconsin

West Virginia

Wyoming 
Table 2b

Legal Enforcement Governance Sub-Index

\begin{tabular}{|c|c|c|c|c|c|}
\hline State & $\begin{array}{c}\text { AG } \\
\text { notice of } \\
\text { suits }\end{array}$ & $\begin{array}{c}\text { Other } \\
\text { party } \\
\text { standing }\end{array}$ & $\begin{array}{c}\text { Cy } \\
\text { pres }\end{array}$ & $\begin{array}{c}\text { Total } \\
\text { Enforcement } \\
\text { Sub-Index }\end{array}$ & $\begin{array}{l}\text { Total } \\
\text { Legal } \\
\text { Index }\end{array}$ \\
\hline Alaska & 0 & 0 & 0 & 0 & 2 \\
\hline Alabama & 0 & 1 & 1 & 2 & 4 \\
\hline Arkansas & 0 & 0 & 1 & 1 & 3 \\
\hline Arizona & 0 & 0 & 1 & 1 & 3 \\
\hline California & 1 & 1 & 1 & 3 & 7 \\
\hline Colorado & 0 & 1 & 1 & 2 & 4 \\
\hline Connecticut & 1 & 1 & 1 & 3 & 5 \\
\hline $\mathrm{DC}$ & 0 & 1 & 1 & 2 & 4 \\
\hline Delaware & 1 & 1 & 1 & 3 & 4 \\
\hline Florida & 0 & 1 & 1 & 2 & 4 \\
\hline Georgia & 1 & 1 & 1 & 3 & 6 \\
\hline Hawaii & 0 & 1 & 1 & 2 & 3 \\
\hline Iowa & 1 & 0 & 1 & 2 & 4 \\
\hline Idaho & 1 & 1 & 1 & 3 & 5 \\
\hline Illinois & 1 & 1 & 1 & 3 & 5 \\
\hline Indiana & 1 & 0 & 1 & 2 & 4 \\
\hline Kansas & 1 & 0 & 1 & 2 & 4 \\
\hline Kentucky & 0 & 0 & 1 & 1 & 3 \\
\hline Louisiana & 1 & 0 & 1 & 2 & 4 \\
\hline Massachusetts & 1 & 1 & 1 & 3 & 6 \\
\hline Maryland & 0 & 1 & 1 & 2 & 4 \\
\hline Maine & 0 & 0 & 1 & 1 & 4 \\
\hline Michigan & 1 & 1 & 1 & 3 & 5 \\
\hline Minnesota & 1 & 1 & 1 & 3 & 6 \\
\hline Missouri & 1 & 1 & 1 & 3 & 6 \\
\hline Mississippi & 1 & 1 & 1 & 3 & 4 \\
\hline Montana & 1 & 1 & 1 & 3 & 6 \\
\hline North Carolina & 1 & 1 & 1 & 3 & 6 \\
\hline North Dakota & 1 & 1 & 1 & 3 & 6 \\
\hline Nebraska & 1 & 1 & 1 & 3 & 6 \\
\hline New Hampshire & 0 & 0 & 1 & 1 & 2 \\
\hline New Jersey & 1 & 1 & 1 & 3 & 5 \\
\hline New Mexico & 0 & 0 & 1 & 1 & 3 \\
\hline Nevada & 1 & 1 & 1 & 3 & 5 \\
\hline New York & 1 & 1 & 1 & 3 & 6 \\
\hline Ohio & 1 & 1 & 1 & 3 & 5 \\
\hline Oklahoma & 1 & 1 & 1 & 3 & 4 \\
\hline Oregon & 1 & 1 & 1 & 3 & 7 \\
\hline Pennsylvania & 1 & 1 & 1 & 3 & 5 \\
\hline Rhode Island & 1 & 0 & 1 & 2 & 4 \\
\hline South Carolina & 1 & 1 & 0 & 2 & 6 \\
\hline South Dakota & 1 & 0 & 1 & 2 & 4 \\
\hline Tennessee & 1 & 1 & 1 & 3 & 6 \\
\hline Texas & 1 & 1 & 1 & 3 & 5 \\
\hline Utah & 1 & 0 & 1 & 2 & 3 \\
\hline Virginia & 1 & 0 & 1 & 2 & 4 \\
\hline Vermont & 1 & 1 & 1 & 3 & 6 \\
\hline Washington & 1 & 0 & 1 & 2 & 5 \\
\hline Wisconsin & 1 & 1 & 1 & 3 & 5 \\
\hline West Virginia & 0 & 0 & 1 & 1 & 2 \\
\hline Wyoming & 1 & 1 & 1 & 3 & 6 \\
\hline
\end{tabular}


Table 3

Reporting Governance Index

State

Alaska

Alabama

Arkansas

Arizona

California

Colorado

Connecticut

DC

Delaware

Florida

Georgia

Hawaii

Iowa

Idaho

Illinois

Indiana

Kansas

Kentucky

Louisiana

Massachusetts

Maryland

Maine

Michigan

Minnesota

Missouri

Mississippi

Montana

North Carolina

North Dakota

Nebraska

New Hampshire

New Jersey

New Mexico

Nevada

New York

Ohio

Oklahoma

Oregon

Registe

$\begin{array}{rl}159 & 1 \\ 474 & 1 \\ 176 & 1 \\ 472 & 1 \\ 5,121 & 1 \\ 812 & 1 \\ 1,060 & 1 \\ 1,464 & 1 \\ 218 & 0 \\ 2,007 & 1 \\ 843 & 1 \\ 271 & 0 \\ 529 & 0 \\ 61 & 0 \\ 2,244 & 1 \\ 1,045 & 0 \\ 457 & 1 \\ 529 & 1 \\ 383 & 1 \\ 1,691 & 1 \\ 987 & 1 \\ 275 & 1 \\ 1,267 & 1 \\ 1,079 & 1 \\ 911 & 1 \\ 202 & 1 \\ 122 & 0 \\ 1,340 & 1 \\ 104 & 1 \\ 324 & 0 \\ 274 & 1 \\ 1,227 & 1 \\ 150 & 1 \\ 93 & 0 \\ 5,482 & 1 \\ 2,474 & 1 \\ 435 & 1 \\ 449 & 1\end{array}$

\section{Fundraiser}

Financials

By-laws Articles 1023

Addl.

Total

Reporting

Index

5

5

5

3

6

3

3

4

6

0

0

7

6

2

4

6

5

8

6

6

9

8

8

0
7
8

6

0

6

6

4
5 
Table 3

Reporting Governance Index (continued)

\begin{tabular}{|c|c|c|c|c|c|c|c|c|c|c|c|}
\hline State & Obs. & Register & Annual & Fundraiser & Audit & Financials & By-laws & Articles & 1023 & Addl. & $\begin{array}{l}\text { Reporting } \\
\text { Index }\end{array}$ \\
\hline Pennsylvania & 2,850 & 1 & 1 & 0 & 1 & 1 & 1 & 1 & 1 & 0 & 7 \\
\hline Rhode Island & 308 & 1 & 1 & 1 & 1 & 1 & 0 & 0 & 0 & 1 & 6 \\
\hline South Carolina & 411 & 1 & 1 & 1 & 0 & 1 & 0 & 0 & 0 & 0 & 4 \\
\hline South Dakota & 193 & 0 & 0 & 0 & 0 & 0 & 0 & 0 & 0 & 0 & 0 \\
\hline Tennessee & 719 & 1 & 1 & 1 & 1 & 1 & 1 & 1 & 1 & 2 & 10 \\
\hline Texas & 2,055 & 0 & 0 & 0 & 0 & 0 & 0 & 0 & 0 & 0 & 0 \\
\hline Utah & 102 & 1 & 1 & 1 & 1 & 0 & 1 & 1 & 1 & 1 & 8 \\
\hline Virginia & 1,363 & 1 & 1 & 1 & 1 & 1 & 1 & 1 & 1 & 0 & 8 \\
\hline Vermont & 160 & 0 & 0 & 0 & 0 & 0 & 0 & 0 & 0 & 0 & 0 \\
\hline Washington & 696 & 1 & 1 & 1 & 0 & 1 & 0 & 0 & 1 & 1 & 6 \\
\hline Wisconsin & 933 & 1 & 1 & 0 & 1 & 1 & 1 & 1 & 1 & 0 & 7 \\
\hline West Virginia & 179 & 1 & 0 & 1 & 1 & 0 & 0 & 0 & 1 & 1 & 5 \\
\hline Wyoming & 89 & 0 & 0 & 0 & 0 & 0 & 0 & 0 & 0 & 0 & 0 \\
\hline
\end{tabular}


Variable:

Governance Variables:

Non-distribution governance

Enforcement governance

Reporting governance

Charitable Not-for-profits:

Charitable expenses / total expenses

Charitable expenses / total revenues

Fundraising indicator

Officer compensation / total expenses

Officer compensation / other

employee compensation

Total revenues (in \$millions)

Total assets (in \$millions)

Total donation (in \$millions)

Percentage change in total donations

Percentage change in program revenues

Percentage change in asset sales

Percentage change in state disposable income

Percentage change in state disposable income per capita

Percentage change in gross state product

Percentage change in state unemployment

Percentage changes in charitable expenditures
Mean

Median

$25 \%$

$75 \%$

Std.Dev

$\begin{array}{lllll}2.51 & 2.00 & 2.00 & 3.00 & 0.76 \\ 3.44 & 4.00 & 3.00 & 4.00 & 0.83 \\ 5.62 & 6.00 & 5.00 & 7.00 & 2.46\end{array}$

$\begin{array}{rrrrr}0.785 & 0.839 & 0.73 & 0.90 & 0.20 \\ 0.676 & 0.734 & 0.49 & 0.86 & 0.29 \\ 0.060 & 0.000 & 0.00 & 0.00 & 0.23 \\ 0.059 & 0.032 & 0.01 & 0.06 & 0.08 \\ 0.346 & 0.217 & 0.00 & 0.70 & 0.37 \\ 13.26 & 4.18 & 1.11 & 11.43 & 47.79 \\ 29.09 & 11.29 & 2.48 & 25.77 & 86.46 \\ 6.61 & 1.02 & 0.21 & 4.08 & 27.72 \\ -0.61 & 0.04 & -0.28 & 0.307 & 3.57 \\ -0.20 & 0.06 & -0.05 & 0.17 & 1.33 \\ -0.09 & 0.62 & -0.21 & 1.00 & 14.36 \\ -0.02 & 0.04 & 0.03 & 0.06 & 0.27 \\ -0.01 & 0.03 & 0.02 & 0.05 & 0.20 \\ -0.02 & 0.05 & 0.03 & 0.06 & 0.28 \\ -0.01 & -0.05 & -0.13 & 0.10 & 0.19 \\ -0.19 & 0.05 & -0.04 & 0.15 & 1.16\end{array}$

Private Foundations:

Qualifying distributions / required

distributions

$\begin{array}{rrrrr}3.16 & 1.13 & 0.97 & 1.65 & 9.58 \\ 0.27 & 0 & 0 & 1 & 0.44 \\ 0.50 & 0.53 & 0.23 & 0.77 & 0.29 \\ 4.87 & 1.68 & 0.67 & 4.07 & 10.90 \\ 23.98 & 1.76 & 0.28 & 11.68 & 232.87 \\ 3.16 & 1.13 & 0.97 & 1.65 & 9.58\end{array}$

Notes: The governance variables are described in Tables 1a and 1b. Charitable expenses are expenses directed towards accomplishing the charitable mission rather than for fundraising or administrative activities. The fundraising indicator is equal to one if the ratio of fundraising expenses to donations received is one or greater, and zero otherwise. Officers compensation for charitable purposes is the amount of officers compensation that is allocated to activities that accomplish the charitable mission rather than those allocated to fundraising or administrative activities. Program revenues are from the sales of products and services. Qualifying distributions are amounts paid by a foundation that qualify towards meeting the five percent payout minimum. Required distributions are five percent of total assets. The delayed distribution indictor variable is equal to one of the foundation times its payouts such they are as late as possible (i.e., in the following year) and zero otherwise. 
Table 5

Dependent Variable: Ratio of Charitable Expense to Total Expense Ratio of Charitable Expense to Total Revenue
(1)
(2)
(3)
(4)
(5)

Constant

Combined

Governance

$\begin{array}{llllll}0.657 & 0.657 & 0.671 & 0.653 & 0.657 & 0.654\end{array}$

$\begin{array}{llllll}(66.14) & (60.40) & (88.19) & (58.68) & (59.90) & (58.59)\end{array}$

0.003

(3.61)

Legal Governance

$\begin{array}{ll}0.005 & 0.004\end{array}$

(3.17)

(2.26)

Distribution

Sub-index

\section{Enforcement}

Sub-index

Reporting Governance

Industry Effects?

Size Controls?

Revenue Controls?

No. of Observations

0.003

(3.93)

$\begin{array}{rr}0.005 & 0.003 \\ (2.74) & (1.64)\end{array}$

(1.85) (1.89)

$0.004 \quad 0.002$

(1.66) (0.65)

$\begin{array}{lll}0.003 & 0.002 & 0.002 \\ (3.01) & (2.23) & (2.29)\end{array}$

$\begin{array}{cccccc}\mathrm{Y} & \mathrm{Y} & \mathrm{Y} & \mathrm{Y} & \mathrm{Y} & \mathrm{Y} \\ \mathrm{Y} & \mathrm{Y} & \mathrm{Y} & \mathrm{Y} & \mathrm{Y} & \mathrm{Y} \\ \mathrm{Y} & \mathrm{Y} & \mathrm{Y} & \mathrm{Y} & \mathrm{Y} & \mathrm{Y}\end{array}$

(7) (8) (9) (10) (11) (12)

\begin{tabular}{|rrrrrr}
$(7)$ & $(8)$ & $(9)$ & $(10)$ & $(11)$ & $(12)$ \\
0.539 & 0.544 & 0.556 & 0.538 & 0.545 & 0.540 \\
$(46.15)$ & $(40.50)$ & $(63.69)$ & $(39.43)$ & $(40.29)$ & $(39.43)$
\end{tabular} \mid$(-10$

(13) (14) (15) (16) (17)

Fundraising Indicator Variable

$\begin{array}{rrrrrr}-2.634 & -2.755 & -2.863 & -2.687 & -2.774 & -2.713 \\ (-10.61) & (-10.3) & (-13.86) & (-10.08) & (-10.16) & (-9.92) \\ -0.054 & & & & & \end{array}$

$(-2.55)$

$\begin{array}{ll}-0.074 & -0.045 \\ (-1.80) & (-0.95)\end{array}$

$-0.145-0.143$

$(-2.05)(-2.04)$

$-0.014 \quad 0.061$

$51,756 \quad 51,756 \quad 51,756 \quad 51,756 \quad 51,756 \quad 51,756$

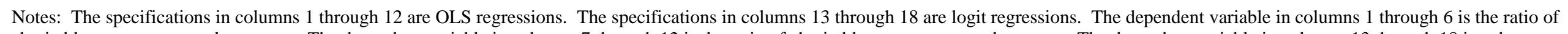

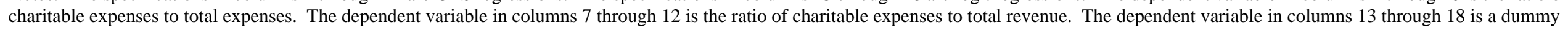

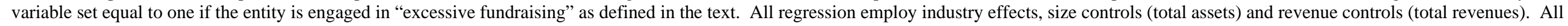
t-statistics (in parentheses) are based on standard errors clustered at the entity level. Governance variables are described in Tables 1a and 1b. 
Table 6

Dependent Variable: Ratio of Officer’s Compensation to Total Expense
(1)
(2)
(3)
(4)
(5)

(6)

)

Constant

$\begin{array}{rr}0.078 & 0.071 \\ (16.69) & (13.49)\end{array}$

0.078

0.073

(22.29) (13.48) (13.42)

$-.001$

Combined
Governance

$$
(-1.39)
$$

Legal Governance

$$
0.000
$$

0.001

(0.45)

Distribution

Sub-index

Enforcement

Sub-index

\section{Reporting}

Governance

Industry Effects?

Size Controls?

Revenue Controls?

No. of Observations

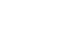

Ratio of Officer's Comp. to Other Employee Compensation

$$
\begin{aligned}
& \begin{array}{llll}
(7) & (8) \quad(9) \quad(10)
\end{array} \\
& \begin{array}{llllll}
0.311 & 0.304 & 0.284 & 0.315 & 0.305 & 0.316
\end{array} \\
& \text { (13.16) (11.90) (16.95) (11.72) (11.84) (11.77) } \\
& -.005 \\
& (-2.83) \\
& -.008 \quad-.006 \\
& (-2.23) \quad(-1.55) \\
& -.007 \quad-.007 \\
& (-.97) \quad(-1.08) \\
& -.010 \quad-.005 \\
& (-1.58) \quad(-0.77) \\
& -.005 \quad-.005 \\
& (-2.47) \quad(-2.02) \\
& -.005 \\
& 25,831 \quad 25,831 \quad 25,831 \quad 25,831 \quad 25,831 \quad 25,831
\end{aligned}
$$

$\begin{array}{cccccc}\mathrm{Y} & \mathrm{Y} & \mathrm{Y} & \mathrm{Y} & \mathrm{Y} & \mathrm{Y} \\ \mathrm{Y} & \mathrm{Y} & \mathrm{Y} & \mathrm{Y} & \mathrm{Y} & \mathrm{Y} \\ \mathrm{Y} & \mathrm{Y} & \mathrm{Y} & \mathrm{Y} & \mathrm{Y} & \mathrm{Y}\end{array}$

Notes: All specifications are OLS regressions. The dependent variable in columns 1 through 6 is the ratio of officer's compensation to total expenses. The dependent variable in columns 7 through 12 is the ratio of officer's compensation to total employee compensation. All regression employ industry effects, size controls (total assets) and revenue controls (total revenues). All t-statistics (in parentheses) are based on standard errors clustered at the entity level. Governance variables are described in Tables $1 \mathrm{a}$ and $1 \mathrm{~b}$. 
Table 7

Effects of Governance on Foundation Payouts

Dependent Variable:

Ratio of Current Year Payout to Prior Year Distributable Amount

\begin{tabular}{|c|}
\hline Constant \\
\hline Combined Governance \\
\hline
\end{tabular}

Legal Governance

Non-Distribution Subindex

Enforcement Sub-

index

Reporting Governance

Industry Effects?

Size Controls?

Revenue Controls?

No. of Observations
(1)

(2)

(3)

(4)

(5)

(6)

$\mid \quad$ (7)

355

1.340

1.467

$1.316 \quad 1.370$

1.352

(20.27)

(47.52)

(19.93)

(20.17)

(19.90)

0.041

0.030

(3.77)

(2.59)

\section{0}

(3.86)

(3.74)

0.009

$-0.013$

(0.49)

0.021

0.017

(4.11)

(3.08)

Y Y

Y Y

$\mathrm{Y} \quad \mathrm{Y}$

$Y$
$Y$
$Y$

Y
Y
Y

$38,411 \quad 38,411$

38,411

$38,411 \quad 38,411 \quad 38,411$

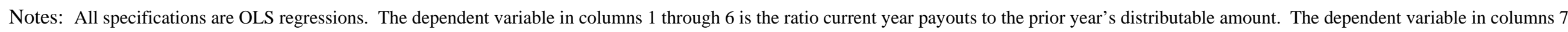

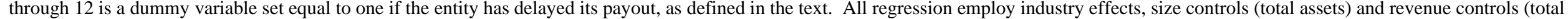
revenues). All t-statistics (in parentheses) are based on standard errors clustered at the entity level. Governance variables are described in Tables $1 \mathrm{a}$ and $1 \mathrm{~b}$. 
Table 8

Effects of Governance on Foundation Officers' Compensation

Dependent Variable:
Ratio of Officer's Compensation to Total Expense

Ratio of Officer's Compensation to Other Employee Compensation

(1)

(2)

(3)

(4)

(5)

(6)

Constant

Combined Governance$$
0.570
$$

0.632

0.545

0.629

(41.10)

(75.70)

(40.91)

0.620

(40.12)

$-0.017$

$(-2.41)$

Legal Governance

Non- Distribution Subindex

Enforcement Sub-index

Reporting Governance

Industry Effects?

Size Controls?

Revenue Controls?

No. of Observations

$$
\begin{array}{r}
-0.015 \\
(-5.78)
\end{array}
$$

$\begin{array}{cccr} & & -0.031 & -0.031 \\ & & (-6.57) & (-6.61) \\ & & 0.000 & -0.003 \\ & & (-0.05) & (-0.51) \\ 0.000 & 0.003 & & 0.002 \\ (-0.12) & (2.13) & & (1.23) \\ & & & \\ Y & Y & Y & Y \\ Y & Y & Y & Y \\ Y & Y & Y & Y \\ 33,516 & 33,516 & 33,516 & 33,516\end{array}$

(7)

(8)

(8)

(9) $\quad(10)$

(10) (11)

(12)

$\begin{array}{rrrrrr}6.765 & 6.715 & 5.591 & 7.143 & 6.361 & 6.837 \\ (37.09) & (29.93) & (51.55) & (30.68) & (29.58) & (30.97)\end{array}$

$-0.203$

$(-13.87)$

$\begin{array}{rr}-0.384 & -0.281 \\ (-10.51) & (-7.79)\end{array}$

$\begin{array}{rr}-0.772 & -0.706 \\ (-12.36) & (-11.36) \\ -0.011 & 0.103 \\ (-0.19) & (1.67) \\ & -0.187 \\ & (-9.71)\end{array}$

$\begin{array}{rrr}-0.216 & -0.185 & -0.187 \\ (-13.10) & (-11.05) & (-9.71)\end{array}$

Notes: All specifications are OLS regressions. The dependent variable in columns 1 through 6 is the ratio of officer's compensation to total expenses. The dependent variable in columns 7 through 12 is the ratio of officer's compensation to total employee compensation. All regression employ industry effects, size controls (total assets) and revenue controls (total revenues). All t-statistics (in parentheses) are based on standard errors clustered at the entity level. Governance variables are described in Tables 1a and 1b. 


\begin{tabular}{|c|c|c|c|c|c|}
\hline & (1) & (2) & (3) & (4) & (5) \\
\hline \multirow[t]{2}{*}{ Intercept } & -1.501 & -1.164 & -1.680 & -0.998 & -0.997 \\
\hline & $(-133.0)$ & $(-109.2)$ & $(-119.6)$ & $(-73.8)$ & $(-73.03)$ \\
\hline \multirow[t]{2}{*}{$\begin{array}{l}\text { Legal governance indicator } \\
\text { variable }\end{array}$} & & & & & -0.002 \\
\hline & & & & & $(-0.64)$ \\
\hline \multirow[t]{2}{*}{ Change in donations } & 0.044 & & & 0.020 & 0.020 \\
\hline & $(38.7)$ & & & $(14.11)$ & $(14.08)$ \\
\hline \multirow{2}{*}{$\begin{array}{l}\text { Change in donations * governance } \\
\text { indicator }\end{array}$} & -0.007 & & & 0.001 & 0.001 \\
\hline & $(-4.02)$ & & & $(0.58)$ & $(0.47)$ \\
\hline \multirow[t]{2}{*}{ Change in program revenue } & & 0.310 & & 0.200 & 0.200 \\
\hline & & $(112.2)$ & & $(47.40)$ & $(47.31)$ \\
\hline \multirow{2}{*}{$\begin{array}{l}\text { Change in program revenue * } \\
\text { governance indicator }\end{array}$} & & -0.058 & & -0.054 & -0.053 \\
\hline & & $(-13.82)$ & & $(-9.22)$ & $(-8.96)$ \\
\hline \multirow[t]{2}{*}{ Change in asset sales revenue } & & & 0.000 & 0.000 & 0.000 \\
\hline & & & $(0.56)$ & $(-0.28)$ & $(-0.28)$ \\
\hline \multirow[t]{2}{*}{$\begin{array}{l}\text { Change in asset sales revenue * } \\
\text { governance indicator }\end{array}$} & & & 0.000 & 0.000 & 0.000 \\
\hline & & & $(-0.31)$ & $(0.33)$ & $(0.31)$ \\
\hline Year Effects? & $\mathrm{Y}$ & $\mathrm{Y}$ & $\mathrm{Y}$ & $\mathrm{Y}$ & $\mathrm{Y}$ \\
\hline Industry Effects? & $\mathrm{Y}$ & $\mathrm{Y}$ & $\mathrm{Y}$ & $\mathrm{Y}$ & $\mathrm{Y}$ \\
\hline No. of Observations & 41,045 & 30,363 & 21,360 & 15,679 & 15,680 \\
\hline R-Squared & 0.40 & 0.62 & 0.44 & 0.47 & 0.47 \\
\hline
\end{tabular}

Notes: All specifications are OLS regressions. The dependent variable is the annual percentage change in charitable expenses. The governance indicator variable is equal to 1 if the legal governance variable (the combination of non-distribution and enforcement governances) is greater than 6 (its median value) and zero otherwise. Donations are the total donations received by an organization. Program revenues are those from the sales of products and services. Asset sales revenues are from the sales of assets including investments and equipment. All regressions employ industry effects and yearly indicator variables. T-statistics based on robust standard errors are underneath the parameter estimates. 


\begin{tabular}{|c|c|c|c|c|c|c|c|c|}
\hline & (1) & (2) & (3) & (4) & (5) & (6) & (7) & (8) \\
\hline \multirow[t]{2}{*}{ Constant } & 0.287 & 0.281 & 0.698 & 0.688 & 0.266 & 0.263 & -1.419 & -1.414 \\
\hline & $(15.90)$ & $(15.58)$ & $(36.31)$ & $(35.76)$ & (15.03) & $(14.87)$ & $(-117.4)$ & $(-117.1)$ \\
\hline \multirow[t]{2}{*}{ Change in disposable income } & 2.019 & 2.035 & & & & & & \\
\hline & $(136.0)$ & $(127.3)$ & & & & & & \\
\hline \multirow{2}{*}{$\begin{array}{l}\text { Change in disposable income * } \\
\text { governance indicator }\end{array}$} & & -0.054 & & & & & & \\
\hline & & $(-3.18)$ & & & & & & \\
\hline \multirow[t]{2}{*}{$\begin{array}{l}\text { Change in per-capita disposable } \\
\text { income }\end{array}$} & & & 3.067 & 3.096 & & & & \\
\hline & & & $(147.2)$ & $(140.0)$ & & & & \\
\hline \multirow[t]{2}{*}{$\begin{array}{l}\text { Change in per-capita disposable } \\
\text { income * governance indicator }\end{array}$} & & & & -0.074 & & & & \\
\hline & & & & $(-3.30)$ & & & & \\
\hline \multirow[t]{2}{*}{ Change in gross state product } & & & & & 1.910 & 1.928 & & \\
\hline & & & & & $(138.25)$ & $(128.2)$ & & \\
\hline \multirow[t]{2}{*}{$\begin{array}{l}\text { Change in gross state product * } \\
\text { governance indicator }\end{array}$} & & & & & & -0.049 & & \\
\hline & & & & & & $(-3.00)$ & & \\
\hline \multirow{2}{*}{$\begin{array}{l}\text { Change in state unemployment } \\
\text { level }\end{array}$} & & & & & & & -0.709 & -0.756 \\
\hline & & & & & & & $(-51.35)$ & $(-48.42)$ \\
\hline \multirow[t]{2}{*}{$\begin{array}{l}\text { Change in state unemployment } \\
\text { level * governance indicator }\end{array}$} & & & & & & & & 0.147 \\
\hline & & & & & & & & (6.430) \\
\hline Year Effects? & $\mathrm{Y}$ & $\mathrm{Y}$ & $\mathrm{Y}$ & $\mathrm{Y}$ & $\mathrm{Y}$ & $\mathrm{Y}$ & $\mathrm{Y}$ & $\mathrm{Y}$ \\
\hline Industry Effects? & $\mathrm{Y}$ & $\mathrm{Y}$ & $\mathrm{Y}$ & $\mathrm{Y}$ & $\mathrm{Y}$ & $\mathrm{Y}$ & $\mathrm{Y}$ & $\mathrm{Y}$ \\
\hline No. of Observations & 40,987 & 40,989 & 40,986 & 40,974 & 40,986 & 40,983 & 41,194 & 11,008 \\
\hline R-Squared & 0.54 & 0.54 & 0.56 & 0.56 & 0.54 & 0.55 & 0.41 & 0.41 \\
\hline
\end{tabular}

Notes: All specifications are OLS regressions. The dependent variable is the annual percentage change in charitable expenses for public charities. The governance indicator variable is equal to 1 if the legal governance variable (the combination of non-distribution and enforcement governances) is greater than 6 (its median value) and zero otherwise. All regressions employ industry effects and yearly indicator variables. T-statistics based on robust standard errors are underneath the parameter estimates. 